\title{
FIRST RECORD OF THALASSIOSIRA CATHARINENSIS (BACILLARIOPHYTA) FROM ARGENTINEAN MARINE COASTAL WATERS
}

\author{
ANDREA S. LAVIGNE ${ }^{1}$, INÉS SUNESEN ${ }^{1,2}$ and EUGENIA A. SAR ${ }^{1,2^{*}}$
}

\begin{abstract}
Summary: Several ultrastructural analyses of taxa belonging to the genus Thalassiosira from Argentinean coastal waters were carried out, nevertheless, the smaller fraction of the nanoplanktonic Thalassiosira was frequently overlooked. The aim of this study is to show the morphological variation of $T$. catharinensis, to compare material found in marine coastal waters of Anegada Bay, Province of Buenos Aires, with the material analyzed in the protologue and allied taxa, and to record the species for the first time in Argentina, extending its distribution.
\end{abstract}

Key words: Anegada Bay, Argentina, diatoms, first record, marine coastal waters, Thalassiosira catharinensis.

\begin{abstract}
Resumen: Primer registro de Thalassiosira catharinensis (Bacillariophyta) en aguas costeras marinas argentinas. A pesar de que se llevaron a cabo varios estudios ultraestructurales de taxones pertenecientes al género Thalassiosira procedentes de las aguas costeras de la Argentina, la fracción más pequeña de los taxones nanoplanctónicos de Thalassiosira fue pasada por alto con frecuencia. El objetivo de este estudio es mostrar la variabilidad morfológica de T. catharinensis, comparar los materiales encontrados en las aguas marinas costeras de la Bahía Anegada (Provincia de Buenos Aires) con el material analizado en el protólogo y con taxones afines, y registrar la especie por primera vez para Argentina, extendiendo su distribución.
\end{abstract}

Palabras clave: aguas marinas costeras, Argentina, Bahía Anegada, diatomeas, primer registro, Thalassiosira catharinensis

\section{INTRODUCTION}

The genus Thalassiosira Cleve emend. Hasle (1973) is an important component of the marine phytoplankton in coastal environments worldwide. According to the diatom list in DiatomBase (Kociolek et al., 2017) it comprises 381 specific and infraspecific names, including synonyms. The genus Thalassiosira was more or less recently split into new genera: Roundia Makarova (1994), Takanoa Makarova (1994), Shionodiscus Alverson, Kang \& Theriot (2006), Spicaticribra Johansen, Kociolek \& Lowe (2008) and Conticribra StachuraSuchoples \& Williams (2009).

\footnotetext{
${ }^{1}$ División Ficología "Dr. Sebastián A. Guarrera", Facultad de Ciencias Naturales y Museo, Universidad Nacional de La Plata, Argentina.

2 Consejo Nacional de Investigaciones Científicas y Técnicas, CONICET, Argentina.

* easar@fcnym.unlp.edu.ar
}

Ultrastructural analyses of taxa belonging to the genus Thalassiosira from Argentinean coastal waters were carried out by Lange et al. (1983), Sar \& Ferrario (1987), Ferrario \& Sar (1988), Gayoso (1989), Sar (1996), Sar et al. (2001, 2002, 2011), Sunesen \& Sar (2004), Sunesen (2007) and Sar \& Sunesen (2017). Some of the taxa analyzed in the mentioned literature were transferred to Shionodiscus Alverson, Kang \& Theriot in Alverson et al. (2006) and Minidiscus Hasle emend Park in Park et al. (2017), and most part of them corresponds to the microplankton or to the largest fraction of the nanoplankton. By contrast, the smaller fraction of the nanoplanktonic Thalassiosira species was frequently overlooked.

Recently, Garcia \& Mareschi Bissa (2016) and Garcia \& Bärwaldt Dutra (2016) analyzed two small nanoplanktonic species of Thalassiosira from the South Atlantic Ocean. Garcia \& Bärwaldt Dutra (2016) described T. catharinensis Garcia, 
from Praia do Gi, Laguna, Santa Catarina State, Southern of Brazil.

The aim of this study is to show the morphological variation of Thalassiosira catharinensis, a small nanoplanktonic species found for the first time in Argentinean waters, and to compare it with material analyzed in its protologue and other allied taxa.

\section{Material and Methods}

The material analyzed was collected at three locations along Anegada Bay: Los Pocitos $\left(40^{\circ}\right.$ $25^{\prime} 47^{\prime}$ 'S $\left.-62^{\circ} 25^{\prime} 18^{\prime} \mathrm{W}\right)$, Ría del Jabalí (40 $32^{\circ}$ $25^{\prime}$ 'S $\left.-62^{\circ} 17^{\prime} 36^{\prime \prime} \mathrm{W}\right)$ and Bahía San Blas $\left(40^{\circ}\right.$ 32 ' 49" S-62 14 ' 13 ' W), at the southern coast of Province of Buenos Aires, from May 2008 to December 2017. Qualitative samples were taken from the surface layer of the water column (between 0 and $5 \mathrm{~m}$ ) with $30 \mu \mathrm{m}$ net hauls and fixed with $4 \%$ formalin.

In the laboratory, the preserved samples were rinsed with distilled water to remove salt and preservatives, and then the organic matter was oxidized according to Hasle \& Fryxell (1970) and Prygiel \& Coste (2000). The cleaned material was mounted for light (LM) and scanning electron microscopy (SEM) after Ferrario et al. (1995). Permanent mounts were made with Naphrax (Brunel Microscopes, Chippenham, UK).

The raw and treated samples, slides and stubs material were deposited in the Herbarium (index herbariorum LPC), División Ficología "Dr. Sebastián A. Guarrera", Facultad de Ciencias Naturales y Museo, Universidad Nacional de La Plata, under the numbers LPC 11601 to LPC 12146.

Observations were made with a light microscope Zeiss Axiovert $40 \mathrm{CFL}$ (phase contrast and DIC diferential interference contrast). Photomicrographs were taken with a Jeol JSM 6360 LV (JEOL, Tokyo, Japan) scanning electron microscope.

Terminology follows Fryxell \& Hasle (1979), Ross et al. (1979), Syvertsen \& Hasle (1984) and Round et al. (1990). Considering the very small diameter of the analyzed material, fultoportula density in $10 \mu \mathrm{m}$ was determined following Hasle (1983) as: $\mathrm{n} \times \cdot 10 / \pi \times \mathrm{d}$, where $\mathrm{n}$ is the number of marginal fultoportulae observed in the valve and $d$ is the valve diameter.

\section{Results}

Morphological characterization of Anegada Bay's taxon

Fig. 1 A-D

The material presents circular valves (Fig. 1A, B), 6.2-7.4 $\mu \mathrm{m}$ in diameter. The valve is slightly silicified, the valve surface is frequently collapsed (Fig. 1B) and the valve mantle is shallow, 2-3 areolae in height. The striation pattern is radial, areolae are elliptical, 39-43 in $10 \mu \mathrm{m}$, arranged in radial striae, $47-52$ in $10 \mu \mathrm{m}$. The portula pattern is characterized by one central fultoportula, a marginal ring of fultoportulae on the valve mantle, 3.0-3.4 in $10 \mu \mathrm{m}$ (Fig. 1A, B) and a marginal rimoportula (Fig. 1A, arrowhead). The central fultoportula has a very short external (Fig. 1A, B) and internal tube (Fig. 1B, D, arrowheads). The marginal fultoportulae have cylindrical external tubes, and shorter internal tubes (Fig. 1A, B) surrounded by 3 operculate satellite pores (Fig. 1C). The rimoportula is close to one fultoportula of the marginal ring, similar in diameter, with the external tube opening in different direction than the tubes of fultoportulae (Fig. 1A, arrowhead).

The comparison of our taxon with the specimens illustrated by Garcia \& Bärwaldt Dutra (2016: 62, Figs. 1-14) as Thalassiosira catharinensis based on distribution pattern of portulae, density of fultoportulae, location, morphology of the external apertures of fultoportulae and rimoportula, number of satellite pores of the marginal fultoportulae (Table 1), allowed us to determine that both taxa are conspecific. T. catharinensis material from Anegada Bay shows subtle differences with that described in the protologue in size (6.2-7.4 vs. 4.4-6.6 $\mu \mathrm{m})$ and stria density (47-52 vs. 50-60). Valve mantle was described by Garcia \& Bärwaldt Dutra (2016) as 1-2 areolae in height, nevertheless protologue's figures 5-8 show mantle is 2-3 areolae height.

Photographed material: LPC 11644, Ría del Jabalí, 18/01/2009.

Distribution: Thalassiosira catharinensis was scarce in phytoplankton samples in Ría del Jabalí on summer (waters temperature ranged between 18.5 and $19.5^{\circ} \mathrm{C}$ ). This is the first record of the species in Argentinian coastal waters and extends the distribution given by Garcia \& Bärwaldt Dutra 

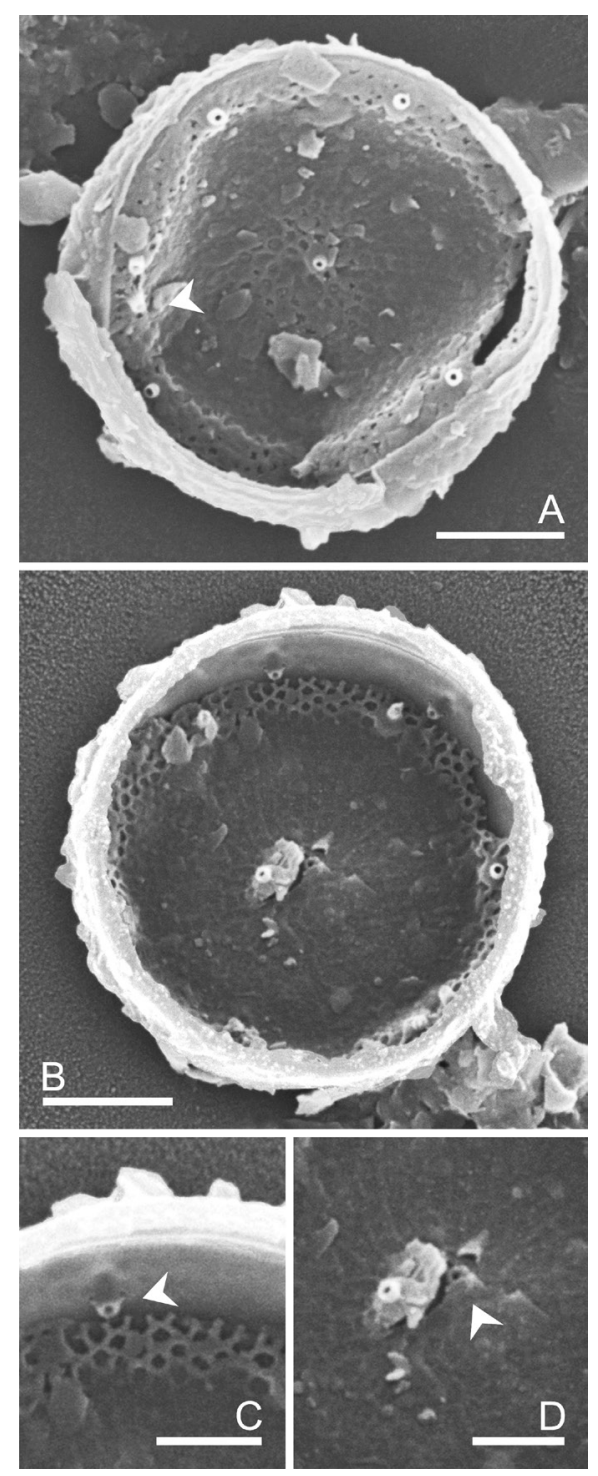

Fig. 1. Thalassiosira catharinensis. SEM. A-D: Valves in external view. A: Frustule showing external tubes of the central fultoportula, the marginal fultoportulae, and a marginal rimoportula close to one fultoportula of the marginal ring (arrowhead), LPC 11644. B: Frustule with a collapsed valve showing external tube of one valve (apparently eccentric due to the displacement of the valve towards one side of the frustule) and internal tube of the other valve. Note marginal fultoportulae in internal view at 2 and 12 o'clock, LPC 11644. C: Detail of the figure B. Note internal view of a marginal fultoportula showing three satellite pores (arrowhead). D: Detail of the broken central area of a valve showing external and internal (arrowhead) tube of the fultoportula. Scale bars: A, B $=2 \mu \mathrm{m} ; \mathrm{C}, \mathrm{D}=1 \mu \mathrm{m}$.
(2016) that described it from Southern Brazil. It occurs in some samples together with $T$. laevis, recently cited by Sar \& Sunesen (2017) from northern coastal waters of the Province of Buenos Aires, Argentina, and found for first time from Anegada Bay during this study.

\section{Discussion}

Thalassiosira catharinensis belongs to the nanoplanktonic size group of the genus with a central fultoportula, a marginal ring of fultoportulae and a marginal rimoportula. T. laevis, T. mala Takano, T. pseudonana Hasle \& Heimdal, T. allenii Takano, T. binata Fryxell and T. conferta Hasle, previously quoted for Argentina, belong to the same group. The comparison between $T$. catharinensis and T. laevis, T. mala, T. profunda (Hendey) Hasle, and T. pseudonana was presented by Garcia \& Bärwaldt Dutra (2016, Table 1). In this study we added comparisons of $T$. catharinensis with other species previously quoted for Argentina having diameter of less than $10 \mu \mathrm{m}$ and sharing portulae pattern.

Thalassiosira catharinensis can be distinguished from T. allenii (Takano, 1965, figs. 2, 9-11; Hasle \& Fryxell, 1978, figs. 100-128) by a higher density of areolae on valve surface, not resolved in LM (39-48 vs. 18-24) and lower density of marginal fultoportulae (3.0-3.4 vs. 5-7).

Thalassiosira binata (Hasle \& Fryxell, 1977, figs. 24-38; Sar et al., 2001, figs. 8-10) is easily distinguished from $T$. catharinensis by the height of the valve mantle (6 vs. 2-3 areolae), the length of the external tubes of the marginal fultoportulae (long vs. short), and the presence of a depressed central areola adjacent to the central fultoportula in T. binata.

Thalassiosira conferta Hasle (Hasle \& Fryxell, 1977, figs. 1-23; Lange et al., 1983, figs. 10-12) differs from $T$. catharinensis by the position and diameter of the rimoportula, placed between two closely located fultoportulae with narrower external tube.

In addition, the comparison was also extended to other members of Thalassiosira belonging to the same group, T. bulbosa Syvertsen, T. oceanica Hasle and T. partheneia Schrader, not quoted for Argentina until now. 
Table 1. Comparison between Thalassiosira catharinensis from Anegada Bay (this study) and Santa Catarina State based on the protologue. Abbreviations: nd, no data; ${ }^{*}$, measured or observed from the protologue's figures.

\begin{tabular}{|c|c|c|}
\hline Thalassiosira catharinensis & Garcia \& Bärwaldt Dutra (2016) & This study $(n=20)$ \\
\hline Diameter in $\mu \mathrm{m}$ & 4.4-6.6 & $6.2-7.4$ \\
\hline Striation pattern & radial & radial \\
\hline \multirow{2}{*}{ Valve mantle, areolae in height } & $1-2$ & \multirow{2}{*}{$2-3$} \\
\hline & $2-3^{*}$ & \\
\hline \multirow{2}{*}{$\begin{array}{l}\text { Striae at the margin of the } \\
\text { valve surface in } 10 \mu \mathrm{m}\end{array}$} & nd & \multirow{2}{*}{$47-52$} \\
\hline & ca. $50-60^{*}$ & \\
\hline Areolae in $10 \mu \mathrm{m}$ on valve face & $39-48$ & $39-43$ \\
\hline $\begin{array}{l}\text { Fultoportulae on valve face: } \\
\text { number, location, morphology }\end{array}$ & 1 central, with external and internal tube & 1 central, with external and internal tube \\
\hline $\begin{array}{l}\text { Marginal fultoportulae in } \\
10 \mu \mathrm{m} \text {, morphology }\end{array}$ & 3.0-3.3, with external and internal tubes & 3.0-3.4, with external and internal tubes \\
\hline $\begin{array}{l}\text { Number of satellite pores of } \\
\text { the marginal fultoportulae }\end{array}$ & 3 , operculate* & 3 , operculate \\
\hline Rimoportula & $\begin{array}{l}\text { one, close to one fultoportula of the } \\
\text { marginal ring, with external tube }\end{array}$ & $\begin{array}{l}\text { one, close to one fultoportula of the } \\
\text { marginal ring, with external tube }\end{array}$ \\
\hline $\begin{array}{l}\text { External aperture of } \\
\text { the rimoportula }\end{array}$ & $\begin{array}{l}\text { cylindrical tube, opening in different } \\
\text { direction than the tubes of fultoportulae }\end{array}$ & $\begin{array}{l}\text { cylindrical tube, opening in different } \\
\text { direction than the tubes of fultoportulae }\end{array}$ \\
\hline
\end{tabular}

Thalassiosira bulbosa Syvertsen (Syvertsen \& Hasle, 1984, figs. 1-32) has marginal fultoportulae with low bulb-shaped outer tubes while $T$. catharinensis presents cylindrical outer tubes, the marginal fultoportulae are denser in the former than in the latter (4.5 vs. 3.0-3.4) and rimoportula is placed between two fultoportulae in the former and next to one fultoportula in the latter.

Thalassiosira oceanica Hasle (Hasle, 1983, figs. 1-18; Park \& Lee, 2010, figs. 15-22) has a marginal ridge structure between the fultoportulae absent in T. catharinensis and Thalassiosira partheneia Schrader (Schrader, 1972, figs. 1-12; Hasle, 1983, figs. 19-33) has long internal tubes of the marginal fultoportulae with two satellite pores while $T$. catharinesis has short internal tubes of the marginal fultoportulae with three satellite pores.

\section{Acknowledgements}

The research was supported by a grant from the Universidad Nacional de La Plata 11/N722 and had the logistical support of the Dirección Provincial de Pesca of the Ministerio de Agroindustria, Province of Buenos Aires.

\section{BibliogRAPHY}

ALVERSON, A. J., S.-H. KANG \& E. C. THERIOT. 2006. Cell wall morphology and systematic importance of Thalassiosira ritscheri (Hustedt) Hasle, with a description of Shionodiscus gen. nov. Diatom Res. 21: 251-262.

FERRARIO, M. E. \& E. A. SAR. 1988. Marine diatoms from Chubut (Argentina Republic) Centrales II Thalassiosira. Rev. Bras. Biol. 48: 421-429.

FERRARIO, M. E., E. A. SAR \& S. E. SALA. 1995. Metodología básica para el estudio del fitoplancton con especial referencia a las diatomeas. In: ALVEAL, K., M. E. FERRARIO, E. C. OLIVEIRA \& E. SAR (eds.), Manual de Métodos Ficológicos, pp. 1-23. Universidad de Concepción, Concepción, Chile.

FRYXELL, G. A. \& G. R. HASLE. 1979. The genus Thalassiosira: species with internal extensions of strutted processes. Phycologia 18: 378-393. 
GARCIA, M. \& D. BÄRWALDT DUTRA. 2016. A new species of nanoplanktonic diatom: Thalassiosira catharinensis (Bacillariophyceae) from Southern of Brazil. Phytotaxa 288: 61-68.

GARCIA, M. \& W. MARESCHI BISSA. 2016. First Record of Thalassiosira laevis Gao \& Cheng for the Southern Hemisphere in the Atlantic Ocean. Diatom 32: 33-37.

GAYOSO, A. M. 1989. Species of the diatom Genus Thalassiosira from a coastal zone of the South Atlantic (Argentina). Bot. Mar. 32: 331-337.

HASLE, G. R. 1973. Thalassiosiraceae, a new Diatom Family. Norw. J. Bot. 20: 67-69.

HASLE, G. R. 1983. The marine, planktonic diatoms Thalassiosira oceanica sp. nov. and T. partheneia. J. Phycol. 19: 220-229.

HASLE, G. R. \& G. A. FRYXELL. 1970. Diatoms: cleaning and mounting for light and electron microscopy. Trans. Amer. Microscop. Soc. 89: 469-474.

HASLE, G. R. \& G. A. FRYXELL. 1977. Thalassiosira conferta and T. binata, two new diatom species. Norw. J. Bot. 24: 239-248.

HASLE, G. R. \& G. A. FRYXELL. 1978. Some Thalassiosira species with one central process (Bacillariophyceae). Norw. J. Bot. 25: 77-110.

JOHANSEN, J., P. KOCIOLEK \& R. LOWE. 2008. Spicaticribra kingstonii, gen. nov. et sp. nov. (Thalassiosirales, Bacillariophyta) from Great Smoky Mountains National Park, U.S.A. Diatom Res. 23: 367-375.

KOCIOLEK, J. P., K. BALASUBRAMANIAN, S. BLANCO, M. COSTE, L. ECTOR, Y. LIU, M. KULIKOVSKIY, N. LUNDHOLM, T. LUDWIG, M. POTAPOVA, F. RIMET, K. SABBE, S. SALA, E. SAR, J. TAYLOR, B. VAN DE VIJVER, C. E.WETZEL, D. M. WILLIAMS, A. WITKOWSKI, \& J. WITKOWSKI. 2017. DiatomBase. Available at: http://www.diatombase.org [Accessed: 2017-12-18].

LANGE, C., R. M. NEGRI \& H. R. BENAVIDES. 1983. Algunas especies del género Thalassiosira (Bacillariophyceae) del Mar Argentino. (Parte 1). Iheringia, Ser. Bot. 31: 9-30.

MAKAROVA, I. V. 1994. The morphology of marine genera of the family Thalassiosiraceae Lebour emend Hasle. In: KOCIOLEK, J. P. (ed.), Proceedings of the 11th International Diatom Symposium. Mem. Calif. Acad. Sci. 17: 103-112.

PARK, J. S. \& J. H. LEE. 2010. A study on the fine structure of marine diatoms in Korean coastal waters: Genus Thalassiosira 5. Algae 25: 121-131.

PARK, J. S., S. W. JUNG, J.-S. KI, R. GUO, H. J. KIM, K.-W. LEE \& J. H. LEE. 2017. Transfer of the small diatoms Thalassiosira proschkinae and T. spinulata to the genus Minidiscus and their taxonomic redescription. PLOS ONE 12(9): e0181980. https://doi. org/10.1371/journal.pone.0181980
PRYGIEL, J. \& M. COSTE. 2000. Guide Méthodologique pour la mise en ouvre de l'Indice Biologique Diatomées. Agences de l'Eau, Ministère de l'Aménagement du Territoire et de l'Environnement, Direction de l'Eau \& CEMAGREF, Cestas.

ROSS, R., E. J. COX, N. I. KARAYEVA, D. G. MANN, T. B. B. PADDOCK, R. SIMONSEN \& P. A. SIMS. 1979. An amended terminology for the siliceous components of the diatom cell. In: SIMONSEN, R. (ed.), Proceedings of the Fourth Symposium on Recent and Fossil Marine Diatoms. Nova Hedwigia, Beih. 64: 513-533.

ROUND, F. E., R. CRAWFORD \& D. G. MANN. 1990. The Diatoms. Morphology and Biology of the Genera. Cambridge University Press, London.

SAR, E. A. 1996. Flora diatomológica de Bahía San Antonio (Prov. de Río Negro, Argentina) O. Centrales I. Rev. Mus. La Plata (n. s.) 14, Bot. 106: 365-400.

SAR, E. A. \& M. E. FERRARIO. 1987. Novedades sobre la distribución de Thalassiosira curviseriata Takano y $T$. pacifica Gran et Angst (Bacillariophyceae) en Argentina. Gayana, Botánica 44: 89-91.

SAR, E. A. \& I. SUNESEN. 2017. Morphological variability of the nanoplanktonic diatom Thalassiosira laevis from coastal waters of Province of Buenos Aires (Argentina). Bol. Soc. Argent. Bot. 52: 617-622.

SAR, E. A., I. SUNESEN \& C. CASTAÑOS. 2001. Marine diatoms from Buenos Aires coastal waters (República Argentina). I. Thalassiosiraceae. Nova Hedwigia 73: 199-228.

SAR, E. A., I. SUNESEN \& A. S. LAVIGNE. 2002. The diatom genus Thalassiosira: species from the northern San Matías Gulf (Río Negro, Argentina). Nova Hedwigia 74: 373-386.

SAR, E. A., I. SUNESEN, A. S. LAVIGNE \& S. LOFEUDO. 2011. Thalassiosira rotula Meunier a heterotypic synonym of Thalassiosira gravida Cleve. Morphological evidence. Diatom Res. 26: 109-119.

SCHRADER, H. J. 1972. Thalassiosira partheneia, eine neue Gallertlager bildende zentrale Diatomee. "Meteor" Forsch. Ergebnisse D 10: 58-64.

STACHURA-SUCHOPLES, K. \& D. M. WILLIAMS. 2009. Description of Conticribra tricircularis, new genus and species of Thalassiosirales, with a discussion on its relationship to other continuous cribra species of Thalassiosira Cleve (Bacillariophyta) and its freshwater origin. Eur. J. Phycol. 44: 477-486.

SUNESEN, I. 2007. Diatomeas de ambientes costeros de la Provincia de Buenos Aires. Análisis taxonómico de los géneros que incluyen especies productoras de floraciones algales nocivas. Doctoral Thesis, Facultad de Ciencias Naturales y Museo. Universidad Nacional de la Plata. 
Bol. Soc. Argent. Bot. 53 (2) 2018

SUNESEN, I. \& E. A. SAR. 2004. Thalassiosira fryxelliae nov. spec. (Bacillariophyceae) from Argentinian coastal waters. Bot. Mar. 47: 238-247.

SYVERTSEN, E. E. \& G. R. HASLE. 1984. Thalassiosira bulbosa Syvertsen, sp. nov., an Arctic marine diatom. Polar Biol. 3: 167-172.
TAKANO, H. 1965. New and rare Diatoms from Japanese marine waters - I. Bull. Tokai Reg. Fish. Res. Lab. 42: 1-10.

Recibido el 4 de enero de 2018, aceptado el 3 de abril de 2018. Editor: Gabriel Bernardello. 